\title{
Technology Transfer as a Prerequisite of Innovative Development of Enterprises
}

\author{
Viktoriia Prokhorova ${ }^{1 *}$, Nadiia Reznik ${ }^{2}$, Olena Bozhanova $^{3}$, Krystyna Slastianykova ${ }^{4}$ \\ ${ }^{1}$ Ukrainian Engineering Pedagogics Academy, Department of Economics and Organization of the \\ Activity of Business Entities, 61003, 16 Universitetskaya st., Kharkiv, Ukraine \\ ${ }^{2}$ National University of Life and Environmental Science of Ukraine, Department of Labor Economics \\ and Rural Development, 03041, 19 Generala Rodimtseva Str, Kyiv, Ukraine \\ ${ }^{3}$ National Metallurgical Academy of Ukraine, Department of Finance, 49600, 4 Gagarina avenue, \\ Dnipro, Ukraine \\ ${ }^{4}$ Ukrainian Engineering Pedagogics Academy, Department of Economics and Organization of the \\ Activity of Business Entities, 61003, 16 Universitetskaya st., Kharkiv, Ukraine
}

\begin{abstract}
Low success in the implementation of technology transfer projects in Ukraine is mainly caused by two groups of factors: the first one, directly related to the development of innovative processes, which hinders the country's participation in the international exchange of technologies, and the second one, caused by the shortcomings of domestic legislation on the definition and protection of intellectual property rights of participants in the innovation process. In order to develop the economy both at the enterprise level and at the national level, the following technology transfers should be developed: firstly, the classical one, which provides for the work of enterprises and research institutions in close relationship; secondly, it requires the development of transformational technology transfer, which ensures closer cooperation in science with other countries; thirdly, it is necessary to attract unique and advanced technologies to the regions. As a result of technology transfer, developments can be successfully commercialized for the benefit of their authors and, as a result, tax revenues to the country's budget can be increased.
\end{abstract}

\section{Introduction}

In the context of globalization and integration, increased competition in world markets, the level of economic development of the country determines its scientific and technological progress and the ability to commercialize intellectual capital. One of the most

*Corresponding author: vkprohkorova@gmail.com 
important components of the innovation process and a promising mechanism of economic stabilization of the state is the transfer of technology, the essence of which is the transfer of know-how, new technologies, technological equipment and scientific and technical knowledge from the owner to the customer.

The issue of determining the essence of the mechanisms of technology transfer has been studied by many domestic and foreign authors, such as S. Arkhiyereyev [1], T. Tarasenko [1], I. Evgrafova [3], H. Pratnenko [4], N. Tkalenko [5], D. Makarov [6], N. Fonshtein [7], L. Balastryk [8], E. Dzhur [9], A. Sadekov [10] and others. Despite the existing scientific developments in this subject area, theoretical and applied issues of the organization and implementation of technology transfer require more in-depth study and improvement. The efficiency of technology transfer is an important factor in the formation of competitive advantages of any enterprise.

\section{Presenting main material}

The process of commercialization of own intellectual capital includes the transfer of new technologies, technological equipment and scientific and technical knowledge from the owner to the consumer. In the developed countries of the world, GDP increases by $75-80 \%$ due to the commercialization of intellectual capital.

In Ukraine, according to UNESCO, the relation between patent activity and GDP growth is the lowest among the countries of the international reference group (correlation index of the USA is 0.985 , Germany -0.916 , UK -0.895 , Poland -0.878 , Ukraine $0.330)[1,2]$.

Low success in the implementation of technology transfer projects in Ukraine is mainly due to two groups of factors: the first one, directly related to the development of innovative processes, which hinders the country's participation in the international exchange of technologies, and the second one, caused by the shortcomings of domestic legislation on the definition and protection of intellectual property rights of participants in the innovation process.

There is no general and free access to the international patent classification of intellectual property objects, which contains not only descriptions, but also characteristics and advantages. Therefore, researchers do not have the opportunity to learn about already developed and patented analogues and their technical specifications which prevents from focusing on the international technology market.

The issue of valuation of intellectual property objects and their reflection in accounting is not settled. Today, so the assessment is extremely difficult because of the use of each time a specially developed technique, which makes this procedure very long and costly. The absence of a unified method of determining the amount of material damage caused by the violation of intellectual property rights makes it impossible to punish violators.

The number of applications for inventions tends to diminish.

These facts confirm the existence of negative trends in the negative losses in the sphere of technological transfer in Ukraine.

Commercial sale of intellectual property is carried out through their actual salehorizontal transfer-and use in their own production - vertical transfer. These two forms of realization of intellectual property objects are interrelated and constantly pass into each other during the life cycle of intellectual property objects. These processes can occur simultaneously or in parallel, with the use of intellectual property objects by different subjects.

Also, scientists decided to identify three main forms of technology transfer:

- internal transfer, when there is a transfer of technology between different organizations; 
- introduce quasi-internal transfer, that is, the movement of technology within alliances, unions and associations of independent legal entities;

- external transfer, i.e. the process of technology diffusion involving independent technology developers and consumers, between different companies and countries [3].

Ukraine has established a national technology transfer network, which has a national scale and aims to promote the commercialization of high-tech technologies and attract the scientific potential of Ukraine in the global commercial turnover [4].

The analysis of the creation of advanced production technologies by industry showed that the dominant role is played by enterprises of mechanical engineering, metallurgical, chemical and petrochemical production, and food industry.

The economy of Ukraine is characterized by an unreasonably long period of use of technologies used in production and, consequently, a high degree of wear and tear of machinery and equipment. These problems can be solved as follows: to transfer technologies by acquiring the results of scientific research of domestic scientists and bringing them to industrial use; to transfer technologies from developed countries.

It should be noted that domestic technologies that are ready for industrial use are not enough, and when purchasing Research \& development results at the early stages of the innovation cycle, the investor bears great risks, since from 100 ideas to the market reach from 5 to 10 . In addition, additional investment is needed, which is about $90 \%$ of the cost of research. In the case of acquisition of foreign technologies, the company does not receive additional revenue from innovation activity, but the risks are minimal, as the products that are released according to the acquired technology has already been tested and received a positive assessment in the market. However, this will not allow the country to become a leader in the world market. Many countries of the world, especially Germany and Japan, paid special attention to the import of technologies, as a result, these countries are now among the world leaders in terms of scientific and technological development.

Today, society is trying to move to an innovative platform for building the economy, from the accumulation of material wealth as the basis of personal well-being - to the accumulation of information as the basis of social progress. The determining priority of the country's place in the globalizing world is the availability of information, intellectual potential and, as a consequence, the possession of material goods in the post-industrial paradigm.

According to N. V. Tkalenko, scientific-technological revolution of the first decades of the XXI century which includes new imperatives, corresponding to the essence of humanistic-noospheric post-industrial society [5].

In order to develop the economy both at the level of enterprises and at the national level, the following technology transfers should be developed. Firstly, the classic one, providing for the work of enterprises and research institutions in close cooperation. Such cooperation provides for making more active use of the results of domestic science and bringing it to industrial and market applications. Secondly, a transformational technology transfer should be developed, ensuring closer cooperation in science with other countries. It is very difficult for domestic enterprises to enter the free world market, as it has long been divided between specialized firms of the USA, Japan, Germany and other developed countries. Selling technologies gives the opportunity to enter the closed market of other countries, because the technology receives related goods and services. Thirdly, unique and advanced technologies to the region should be attracted.

As a result of technology transfer, developments can be successfully commercialized for the benefit of their authors and, as a consequence, tax revenues to the country's budget will be increased. However, developers and owners of new technologies - scientific organizations, small innovative firms, organizations of innovative infrastructure - have problems with finding buyers of their developments or partners to create production. 


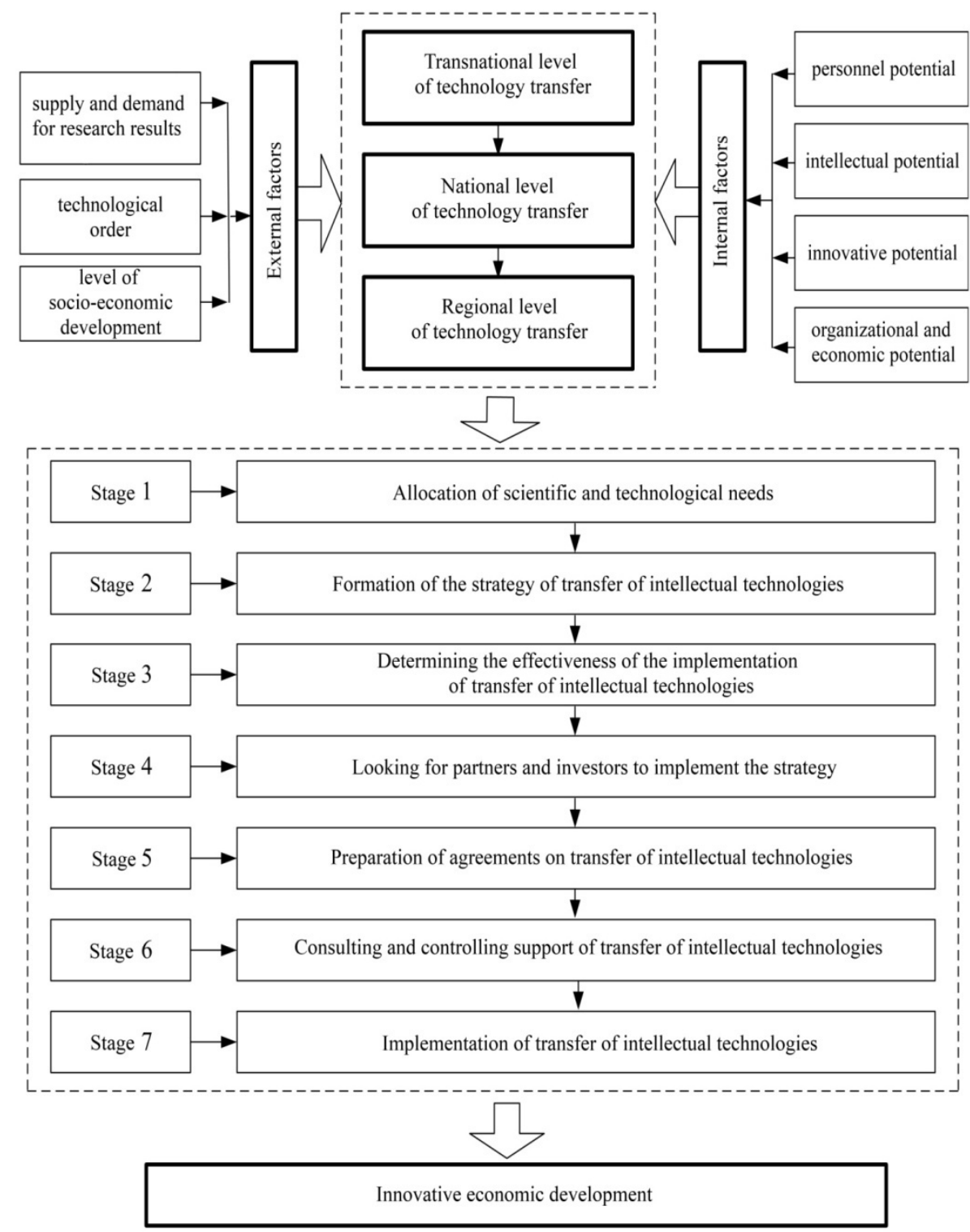

Fig. 1. Stages of implementation of the economic mechanism of technology transfer.

In addition, scientists usually do not have the skills to do business. There is another side to the problem. If the company plans to achieve competitive advantages by improving technologies, then the question will arise where to find information about technologies that can improve business efficiency.

To solve these problems, it is necessary to create institutions-intermediaries of the innovation market, which should provide participants of innovation processes with all necessary services for the development of their potential and innovative opportunities on the principle of "single window".

The efficient transfer of technology accelerates innovation processes at the regional, national and transnational levels. In order to create a mechanism for optimal interaction of organizations on a national and transnational scale, it is necessary to determine the parameters of modeling that allow the most effective way to implement the process of 
technology transfer (Fig. 1). The peculiarity of these parameters is that in determining them it is necessary to take into account the goals and objectives of each of the participants in the process of technology transfer.

Modeling allows obtaining a real system of economic relations with a certain accuracy, taking into account many different components [6]. As the main elements of modeling we can define the following: deepening of analytical approaches aimed at the study of significant economic problems, and the use of new methods in solving economic problems. The most effective mechanism for the implementation of the technology transfer process is a three-level model that allows you to activate the flow of scientific and technological information in short steps. Benefits from the implementation of the three-tier system of technological cooperation are: reduction of time of search of partners and investors; increase in the number of projects with scientific-technological cooperation; increasing the scope of the search for technological partners and investors. The implementation of a three-level technology transfer system will provide additional profit, increase innovation potential, and improve the competitiveness of the economy.

The number of factors influencing the choice of technology transfer mechanism is quite large. The effectiveness of technology transfer should be determined by comparing the costs to the financial result for a certain period of time:

$$
D=\sum_{p=1}^{p}\left[\sum_{i=1}^{n}(V i p * C i p-Z i p)+\sum_{j=1}^{m}(F j p-Z j p)\right](1+k)^{-p}
$$

Where Vip, Cip - the volume and price of innovative products;

Fjp - royalties from the implementation of an innovative product;

$k$ - normal reduction of costs $(\%)$;

$p$ - point in time

Thus, the modeling of the technology transfer process allows us to explore trends and prospects of possible ways to spread innovation. The practical implementation of the threelevel technology transfer system will allow to intensively increase innovation activity in the real sector of the economy.

\section{Conclusions from the conducted research}

For the development of the country's economy, it is necessary to increase the pace of transfer of unique and advanced technologies, attract financial resources for the development of innovation. At the same time, the introduction of innovations in the enterprise should be constant. In addition, during the development and commercialization of new products, it is necessary to focus on the needs of the market, investors, specific buyers of new developments, technologies, goods and services. The experience of developed countries shows that the process of technology transfer can be organized by creating organizations that provide a wide range of services in the field of technology transfer. A particularly important factor in improving the technological level of the country is the commercialization of the results of innovation, for which it is necessary to create tools for technology transfer.

\section{References}

1. Arkhiyereyev S., Tarasenko T. URL: old.niss.gov.ua/Monitor/Oktober/7.htm 
2. Otsinka innovatsiynoho potentsialu Ukrayiny. - Tekhnichna dopovid' № 1 (kviten’ 2013 r.)/ Proekt «Rozbudova spromozhnosti dlia nyz'kovuhletsevoho zrostannia v Ukrayini». - Berlin,(2013)

3. Evgrafova I. Innovatsionnyi menedzhment. URL:Rezhym dostupu: https://www.ereading.club/chapter.php/103739/40/Evgrafova_-

Innovacionnyii_menedzhment._Shpargalka.html

4. Pratnenko H. URL: http://www.irbis-nbuv.gov.ua/cgibin/irbis_nbuv/cgiirbis_64.exe?C21COM=F\&I21DBN=UJRN\&P21DBN=UJRNsoc gum/skhid/2009 7/13.pdf

5. Tkalenko N.V. Naukovyi visnyk CHDIEU, 4, 92-97, (2014)

6. Makarov D.V. Vestnik KRAUNTS. Fiziko-matematicheskiye nauki. 1, 67, (2014)

7. Fonshtein N.M. Transfer tekhnologiy $i$ effektivnaya realizatsiya innovatsiy: khrestomatiya, M. ANKh pri Pravitel'stve RF, 296 (1999)

8. Balastryk L.O. Teoretychni ta prykladni pytannia ekonomiky. Zb. nauk. prats', 7, 188-195, (2005)

9. Dzhur O.Ye. Visnyk ZhDTU. SERIYA: Ekonomichni nauky 4, 290-295, (2012)

10. Sadekov A.A. Upravleniye predpriyatiyem v usloviyakh krizisa: monohrafiya. Donetsk: DonGUET, 178, (2006) 